\title{
STANDARDISASI LAMINASI FRP LAMBUNG KAPAL PENANGKAP IKAN 3 GT Lamination Standard for FRP Hull Fishing Vessel 3 GT
}

\author{
Oktavian Rahardjo', Arfis Maydino², Andi Cahyo² dan Abdul Muis ${ }^{2}$ \\ ${ }^{1}$ Balai Besar Penangkapan Ikan Semarang \\ ${ }^{2}$ Pusat Teknologi Rekayasa Industri Maritim - BPPT Jakarta \\ e-mail: muis918@yahoo.co.uk
}

Diterima: 15 Desember 2017, Direvisi: 24 Januari 2018, Disetujui: 25 Januari 2018

\begin{abstract}
Abstrak
Potensi perikanan wilayah perairan Indonesia cukup besar, yang memerlukan armada penangkapan dalam jumlah yang cukup banyak. Kementerian Kelautan Dan Perikanan tahun 2015 - 2019 memiliki rencana strategis dalam penyediaan bantuan sarana penangkapan ikan untuk nelayan. Pelaksanaannya telah dimulai sejak tahun 2016 dimana telah diserahkan sebanyak 751 unit kapal dan direncanakan 525 unit ditahun 2017. Pada pendistribusiannya di beberapa wilayah menghadapi kendala, desain dan spesifikasinya tidak sesuai dengan kearifan lokal terutama pada kapal-kapal 3 GT. Laminasi yang terlalu tebal, yang menyebabkan kapal lebih berat, kapasitas muatnya lebih kecil, sulit maneuver dan boros penggunaan bahan bakar. Oleh karena program bantuan sarana penangkapan ikan hingga 2019, sehingga kearifan lokal menjadi suatu pertimbangan. Untuk hal tersebut perlunya studi tentang Standarisasi Laminasi FRP Lambung Kapal Penangkap Ikan 3 GT. Studi dilakukan pada kapal kondisi beban maximum dan pada posisi di satu puncak gelombang dan dua puncak gelombang yang dibandingkan dengan hasil laboratorium terhadap laminasi konstruksi kapal 3 GT tersebut. Hasil uji laboratorium menunjukan kekuatan tarik yang lebih besar dari pada perhitungan numerik, dengan safety factor $1.2 \infty 2.98$.
\end{abstract}

Kata kunci : kapal ikan 3 GT, laminasi, stress analysis.

\begin{abstract}
Indonesia's territorial water has a large fishery potential which requiring an abundance of fishing fleets. The Ministry of Marine Affairs and Fisheries strategic plan in 2015 - 2019 is to aid fishing facilities for fishermen. The implementation has been started since 2016, in which 751 units of the ship have been submitted and 525 units are planned to be submitted in 2017. However, the distribution in some areas faces obstacles. However, the design and specifications are not suitable for local wisdom, especially in the 3 GT ships. The thick laminates have resulted in the ship heavier, less loading capacity, maneuver difficulty and inefficient in fuel consumption. Because of the fishing aid program will be running until 2019, the local wisdom becomes a consideration. Therefore, there is an urgency to make a study on the FRP Hull Fishing Vessel 3 GT lamination standard. The study was conducted on a maximum load condition and at position at one wave peak and two wave peaks compared to laboratory results on the 3 GT ship construction laminate. Laboratory result has shown tensile strength more than numeric calculation with safety factor 1.2 to 2.98 .
\end{abstract}

Keywords: fishing vessel 3 GT, lamination, stress analysis.

\section{PENDAHULUAN}

Indonesia sebagai negara kepulauan dengan wilayah perairan mencapai tiga perempat dari total luas wilayah, mempunyai kekayaan sumberdaya kelautan dan perikanan yang melimpah dan dapat menjadi andalan untuk mendukung pembangunan nasional. Salah satu sub sektor yang mempunyai peran penting dalam menunjang pelaksanaan pembangunan kelautan dan perikanan adalah perikanan tangkap. Sub sektor tersebut sangat strategis sebagai penyedia bahan pangan bergizi, lapangan pekerjaan bagi masyarakat, serta memberikan kontribusi dalam menghasilkan devisa negara.
Untuk mewujudkan misi kesejahteraan, salah satu kegiatan prioritas dalam rencana strategis Kementerian Kelautan dan Perikanan tahun 2015-2019 adalah bantuan sarana penangkapan ikan untuk nelayan, yang telah dilaksanakan sejak tahun 2016. Bantuan sarana penangkapan ikan dimaksudkan untuk memperkuat armada perikanan tangkap nasional serta meningkatkan kesejahteraan masyarakat kelautan dan perikanan khususnya nelayan.

Salah satu bentuk bantuan sarana penangkapan ikan adalah kapal penangkap ikan dari bahan fiberglass reinforced plastic (FRP) atau disingkat dengan kapal ikan fiberglass. Menurut data dari Direktorat Kapal Perikanan dan Alat Penangkapan Ikan (Dit. KAPI), 
Direktorat Jendral Perikanan Tangkap (Ditjen. PT), Kementerian Kelautan dan Perikanan (KKP), pada tahun 2016 telah membangun 751 unit kapal ikan fiberglass dengan rincian ukuran : $3 \mathrm{GT}=372$ unit, $5 \mathrm{GT}=181$ unit, $10 \mathrm{GT}=120$ unit, $20 \mathrm{GT}=80$ unit dan $30 \mathrm{GT}=18$ unit. Sedangkan tahun 2017 rencananya akan dibangun kapal ikan fiberglass sebanyak 525 unit dengan rincian ukuran $3 \mathrm{GT}=244$ unit, 5 GT =269 unit, $10 \mathrm{GT}=1$ unit, $20 \mathrm{GT}=5$ unit, 30 GT $=6$ unit.

Dari segi jumlah kapal yang telah dan akan dibangun sangat banyak dengan tujuan antara lain:

1. Meningkatkan kemampuan jelajah operasi dan daya saing nelayan dalam meng-akses potensi di ZEE dan laut lepas sebagai misi kedaulatan;

2. Mengurangi tekanan eksploitasi sumber daya ikan di wilayah perairan pesisir sebagai misi kelestarian sumber daya ikan;

3. Meningkatkan produksi, mutu hasil tangkapan dan produktivitas nelayan, secara ekonomi, sebagai misi kesejahteraan;

4. Meningkatkan pendapatan dan kesejahteraan nelayan sebagai tujuan akhir.

Namun pada pelaksanaan program bantuan kapal perikan pada tahun 2016 mengalami banyak kendala yang dihadapi, khususnya untuk kapal penangkap ikan berukuran 3 GT untuk nelayan di pantai selatan Jawa Barat, walaupun dari segi desain dan konstruksi telah sesuai dan memenuhi kreteria yang diberikan atau ditentukan oleh Biro Klasifikasi Indonesia.

Beberapa alasan yang mengemukan didaerah tersebut antara lain:

1. Desain dan spesifikasi teknis kapal tidak sesuai dengan yang biasa digunakan oleh nelayan setempat (kearifan local);

2. Bobot kapal terlalu berat sehingga mempengaruhi pada kebiasaan nelayan, kecepatan,olah gerak, dan konsumsi bahan bakar minyak (BBM).

Oleh karena Program Bantuan Kapal Perikanan ini berlanjut hingga 2019, sehingga untuk menghindari, mengeliminir ataupun paling tidak meminimalkan penolakan, maka diambil kebijakan untuk memenuhi kearifan lokal dari nelayan calon penerima bantuan atau mengacu desain kapal penangkap ikan sejenis yang existing digunakan oleh daerah asal nelayan calon penerima bantuan. Hipotesa dari perubahan jumlah susunan laminasi yang lebih sedikit dari sebelumnya untuk mendapatkan berat kapal yang lebih ringan masih memenuhi persyaratan dan kebutuhan kekuatan material 256 dari kapal. Namun untuk menjamin keselamatan operasional kapal diperlukan studi justifikasi teknis terutama terhadap konstruksi FRP (susunan laminasi) untuk lambung kapal penangkap ikan bantuan yang akan digunakan. Studi justifikasi teknis dari segi kekuatan terhadap bahan FRP (kekuatan Tarik dan kekuatan bending) yang disajikan dalam bentuk Standarisasi Laminasi lambung Kapal Penangkap Ikan 3 GT berbahan FRP Untuk Kapal Bantuan KKP.

\section{TINJAUAN PUSTAKA}

Kapal nelayan tradisional umumnya terbuat dari bahan kayu, namun saat ini, semakin sulitnya mendapatkan kayu sebagai bahan dasar pembuatan perahu. Harga kayu yang dari hari kehari terus meningkat menyebabkan kapal kayu makin sulit terjangkau oleh nelayan.

Teknologi kapal fibreglass sudah lama dikenal dan telah banyak digunakan sebagai material utama bangunan kapal. Bahan fibreglass memiliki banyak keunggulan dibanding kayu, seperti umur pakainya lebih lama dari kapal kayu dan sedikit perawatan dari pada kapal kayu yang sedikit-sedikit harus dipakal karena bocor serta fibreglass tidak dimakan cacing laut ataupun tritip/kerang laut. Waktu pembuatan kapal fiberglass relatif lebih singkat dan mudah dibentuk dan lebih ringan.

Kapal jenis fiberglass ini memiliki beberapa keunggulan teknis dan ekonomis, sehingga kebutuhannya terus meningkat, namun demikian kekuatan konstruksi lambung kapal sering menjadi penyebab terjadinya kecelakaan di laut. Hasil survei dibeberapa galangan kapal fiberglass menunjukan bahwa desain konstruksi dan proses laminasi lambung kapal fibreglas umumnya tidak mengacu pada persyaratan kelas, sehingga kekuatan konstruksinya sulit dijamin, selain itu galangan kapal tidak memiliki standard enjiniring mengenai penggunaan material/bahan (Buana Ma'ruf, 2011). Beberapa pertimbangan lain dalam melakukan kajian bahan fibreglas antara lain:

1. Pemilihan material untuk bahan lambung kapal tidak hanya karena pertimbangan berat dan kekuatan material semata, melainkan juga pertimbangan tingkat teknologi dan nilai ekonomi. Dengan demikian bahan FRP menjadi pilihan yang paling dominan untuk kapal-kapal berukuran kecil. Kapal berbahan fiberglass juga dapat diproduksi masal (memakai cetakan) dengan waktu cepat, murah dan banyak galangan yang mampu membuatnya karena 
investasinya kecil, teknologinya sederhana dan tidak memerlukan tenaga kerja yang tinggi;

2. Lambung kapal berbahan FRP harus memiliki kekuatan yang memadai dan mampu mengantisipasi gelombang dan benturan benda keras di wilayah pantai. Persyaratan dalam rule kelas mengatur mengenai proses produksi kapal (BKI, 1996). Nilai kuat tarik dan kuat lengkung/tekuk minimum untuk laminasi lambung kapal fiberglass (BKI, 2006), namun kedua rule tersebut hanya diberlakukan untuk kapal berukuran panjang 24 meter keatas, sedang kapal fiberglass yang ber operasi di wilayah pantai Indonesia umumnya berukuran lebih kecil. Akibatnya, kapal-kapal fiberglass berukuran kecil yang umumnya tidak di kelaskan, sulit dijamin kekuatan konstruksi lambungnya;

3. Berdasarkan rules BKI (2006) rules for Non Metalic Materials Part 1, pengujian yang disyaratkan adalah uji tarik dan uji tekuk/lengkung. Rules ini mengacu pada Internasional Standard ISO 14125 (1998) dan ISO 527-4 (1997). Uji tarik bertujuan untuk menentukan nilai tensile strength, fracture strain dan modulus of elasticity, sedangkan uji tekuk bertujuan untuk menentukan nilai bending strength dan modulus of elasticity.

\section{METODE PENELITIAN}

Makalah ini disusun dari hasil rangkaian kegiatan meliputi kajian pustaka, survei lapangan, pembuatan panel benda uji, pengujian panel FRP di laboratorium dan analisa numeric. Tinjauan pustaka mencakup spesifikasi teknis dan desain kapal penangkap ikan <5 GT Bantuan KKP tahun 2016 dan tahun 2017, EN ISO 527-4, DIN EN ISO 14125:2011-05, hasil penelitian serta referensi terkait.

Survei lapangan dilakukan dibeberapa galangan kapal fiberglass di Cilacap yang produknya banyak digunakan oleh nelayan setempat dan pada galangan PT Harapan Teknik Shipyard Cilegon banten dan PT Siagan Boats Makasar. Survei ini bertujuan untuk mengidentifikasi susunan lapisan/laminasi kapal fiberglass. Data dan informasi diperoleh melalui wawancara dan diskusi dengan pekerja digalangan serta pengamatan langsung pada proses pembuatan kapal.

Dibuat panel benda uji digalangan kapal pembangun kapal bantuan KKP tahun 2017 sesuai dengan desain konstruksi lambung. Panel yang dibuat dengan ukuran $55 \mathrm{~cm}$ x 55 cm dipotong sesuai dengan kebutuhan benda uji labotarium untuk dilakukan pengujian Tarik dan kekuatan Bending.

Analisa numeric terhadap desain kapal bantuan bertujuan untuk mendapatkan gambaran besarnya tegangan maximum yang terjadi pada setiap titik di lambung kapal.

\section{HASIL DAN PEMBAHASAN}

Analisa dilakukan terhadap Desain kapal bantuan KKP tahun 2017 untuk kapal 3 GT, bahan utama pembangunan kapal dari FRP dimana konstruksi lambung kapal diperkuat dengan penguat membujur dan melintang yang terbuat dari balok frame fibreglass dengan isi kayu kering dengan ukuran utama kapal 3 GT adalah:

- Panjang Kapal (LOA) : 11.00 Meter

- Lebar Maximum (BMAX): 1.25 Meter

- Tinggi Geladak $(\mathrm{H}) \quad: 0.80$ Meter

- Sarat Benam Air (T) : 0.25 Meter

- Mesin penggerak Outboard Engine : \pm 15 HP, 2 TAK

- $\quad$ Awak kapal (ABK) max. $\quad$ : 4 Orang.
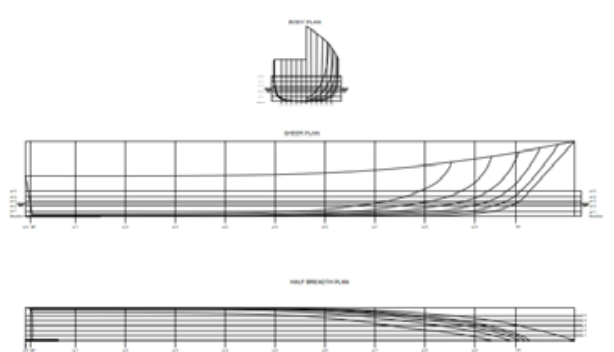

Gambar 1 Rencana Garis.

Analisa dilakukan dua tahap untuk memperoleh tegangan lokal yang terjadi di struktur kapal, yang pertama analisa kekuatan memanjang kapal dan kedua analisa finite elemen metode (FEM)

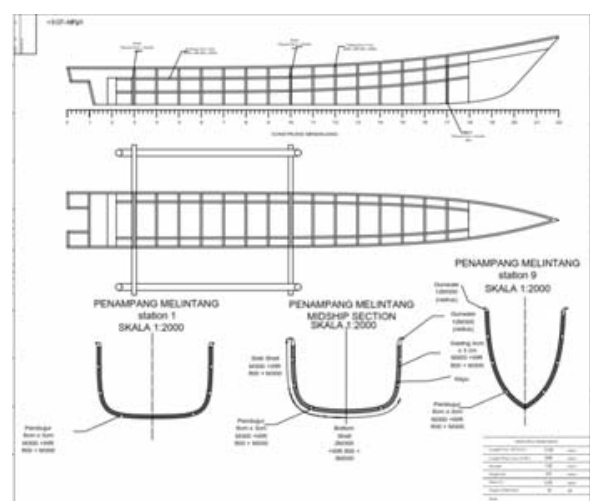

Gambar 2 kontruksi kapal 3GT. 


\section{Analisa Kekuatan memanjang kapal}

Dari gambar rencana garis diatas dibuat model 3D dari lambung kapal untuk kemudian dilakukan analisa kekuatan memanjang kapal sehingga diperoleh nilai moment terbesar dari 3 (tiga) kondisi yaitu: flat, saging dan hogging seperti terlihat pada gambar berikut:

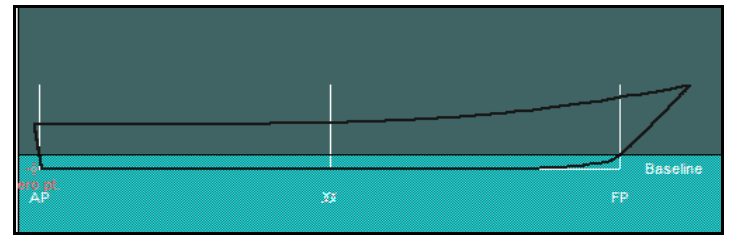

Gambar 3 Kondisi flat

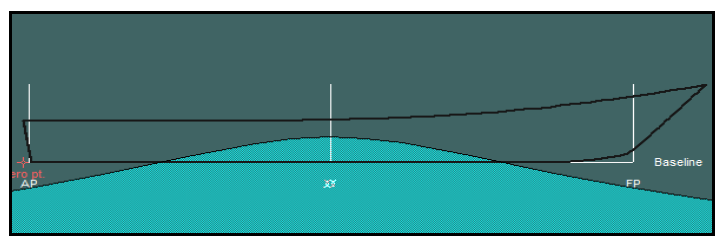

Gambar 4 Kondisi sagging

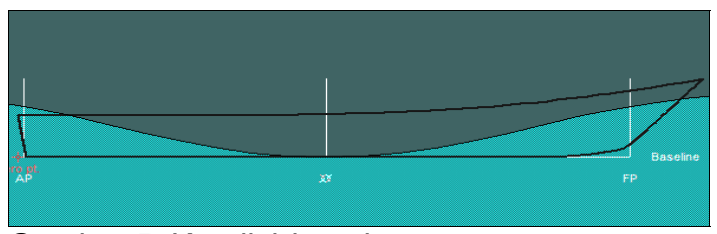

Gambar 5. Kondisi hogging

Asumsi yang digunakan untuk pembebanan dalam perhitungan kekuatan memanjang kapal berdasarkan pada data spesifikasi teknis kapal seperti terlihat pada tabel berikut:

Tabel 1 Pembebanan kapal.

\begin{tabular}{llllccccccc}
\hline \multicolumn{1}{c}{ Item Name } & Quantity & $\begin{array}{c}\text { Unit } \\
\text { Mass } \\
\text { tonne }\end{array}$ & $\begin{array}{c}\text { Total } \\
\text { Mass } \\
\text { tonne }\end{array}$ & $\begin{array}{c}\text { Unit } \\
\text { Volume } \\
\mathbf{m}^{\wedge} \mathbf{3}\end{array}$ & $\begin{array}{c}\text { Total } \\
\text { Volume } \\
\mathbf{m}^{\wedge} \mathbf{3}\end{array}$ & $\begin{array}{c}\text { Long. } \\
\text { Arm } \mathbf{m}\end{array}$ & $\begin{array}{c}\text { Aft. Limit } \\
\mathbf{m}\end{array}$ & $\begin{array}{c}\text { Fwd. } \\
\text { Limit } \mathbf{m}\end{array}$ & $\begin{array}{c}\text { Trans. } \\
\text { Arm } \mathbf{~ m}\end{array}$ & $\begin{array}{c}\text { Vert. } \\
\text { Arm } \mathbf{~}\end{array}$ \\
\hline Lightship & 1 & 0,200 & 0,200 & & & 5,500 & 0,000 & 11,000 & 0,000 & 0,000 \\
Cargo hold & $100 \%$ & 1,341 & 1,341 & 1,490 & 1,490 & 6,691 & & & 0,000 & 0,514 \\
Equipment & 1 & 0,100 & 0,100 & & & 3,621 & 2,500 & 4,750 & 0,000 & 0,250 \\
Crew & 4 & 0,075 & 0,300 & & & 1,000 & 0,000 & 2,000 & 0,000 & 0,800 \\
Engine 1 & 1 & 0,070 & 0,070 & & & 0,000 & 0,000 & 0,000 & $-0,050$ & 0,800 \\
Total Loadcase & & & 2,011 & 1,490 & 1,490 & 5,338 & & & $-0,002$ & 0,502 \\
\hline
\end{tabular}

Dari hasil simulasi dengan bantuan software diperoleh nilai momen yang terjadi dari kondisi sagging dan hogging yang ditampilkan sebagai berikut:

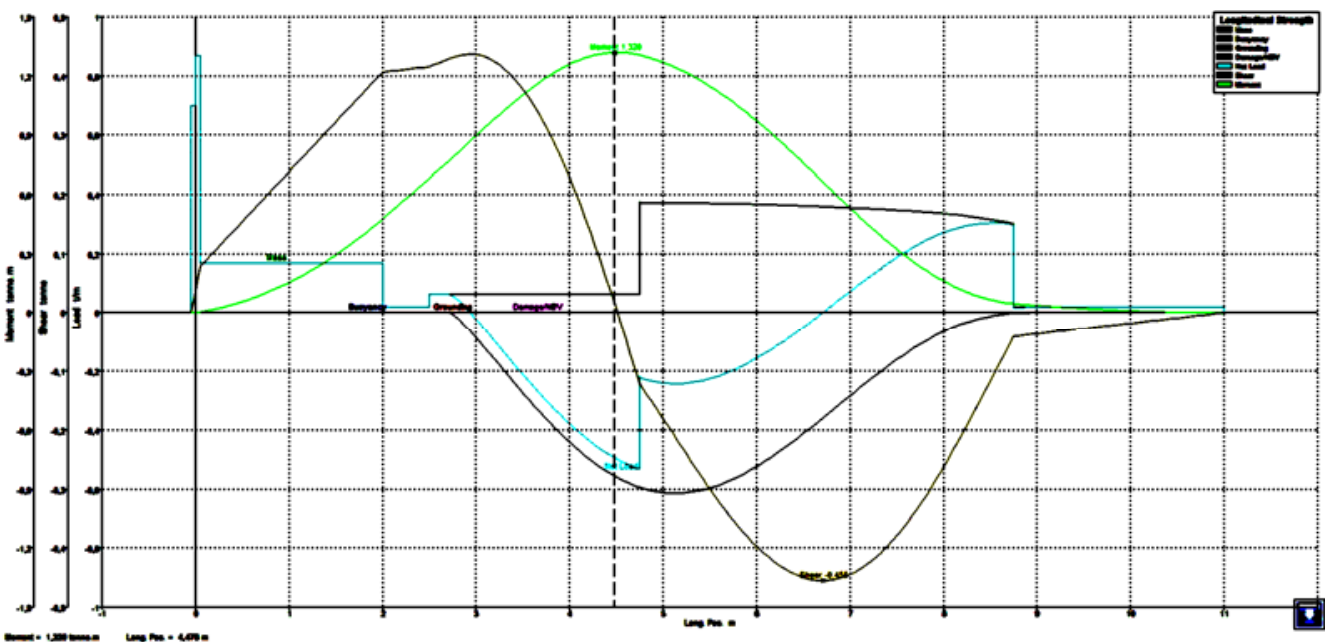

Gambar 6 Grafik hasil perhitungan kekuatan memanjang kondisi sagging. 


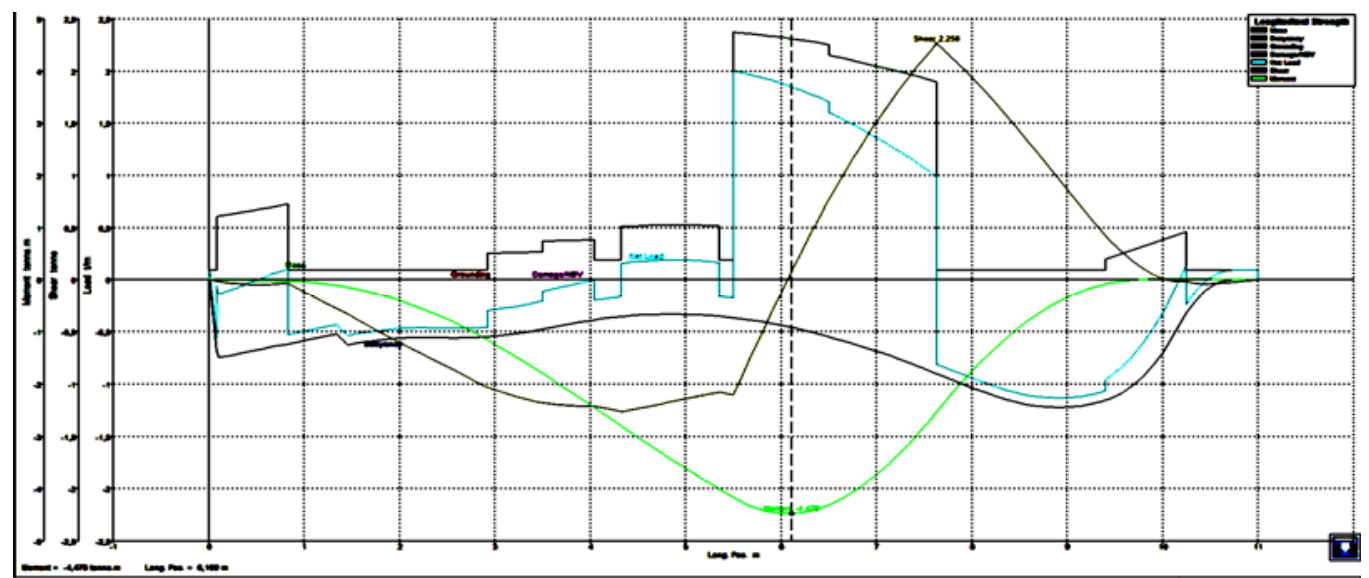

Gambar 7 Grafik 2 hasil perhitungan kekuatan memanjang kondisi hogging.

Dari hasil simulasi dapat disimpulkan bahwa momen tertinggi untuk tiap kondisi adalah sebagai berikut:

Flat $\quad=0.472$ Ton.m, pada frame 10

Sagging $=1.32$ Ton. $\mathrm{m}$, pada frame 13

Hogging $=-\mathbf{1 . 7 0 9}$ Ton.m, pada frame 16

Nilai momen terbesar terjadi pada kondisi hogging sebesar 1,709 ton.m pada frame 16 nilai moment inilah yang menjadi acuan dalam melakukan simulasi FEM untuk mengetahui tegangan maksimum yang bekerja pada daerah tersebut.

\section{Analisa Finite Element Methode (FEM)}

Analisa FEM dilakukan pada bagian kapal yang mengalami moment paling besar berdasarkan hasil analisa kekuatan memanjang yaitu pada kondisi hogging di frame no 16 . Untuk mempermudah simulasi agar mendapatkan nilai tegangan tertinggi maka dimodelkan konstruksi pada frame $15 \mathrm{~s} / \mathrm{d} 17$ seperti terlihat pada gambar berikut:

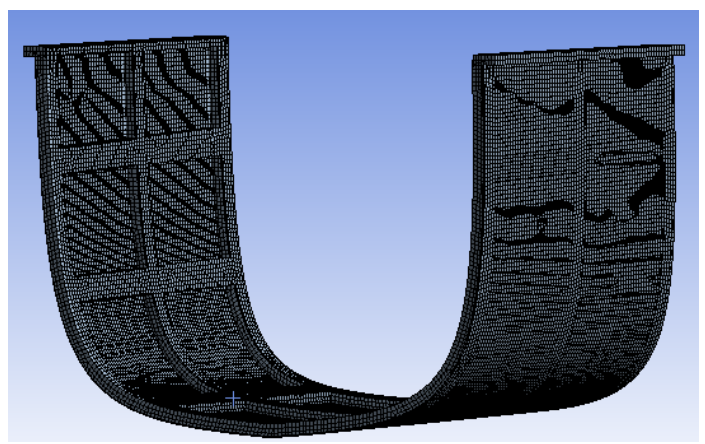

Gambar 8 kontruksi kapal frame 15-17.
Dalam analisa FEM simulasi dilakukan pada 2 model kontruksi laminasi dengan detail kontruksi sebagai berikut:

1) Model 1;

a. Lapisan 1 (Side Shell) menggunakan

Panel 1 berupa FRP 3-layer $(\mathrm{R}+$

CSM300 + R + WR $800+R+$ CSM $300+$ $\mathrm{R})$;

b. Lapisan 2 (Bottom Shell) meng-gunakan Panel 2 berupa FRP 6-layer tipe-1 $(\mathrm{R}+$ CSM300 + R + CSM300 + R + WR800 + $\mathrm{R}+\mathrm{WR} 800+\mathrm{R}+\mathrm{CSM} 300+\mathrm{R}+$ CSM300 + R);

2) Model 2;

a. Lapisan 1 (Side Shell) menggunakan Panel 1 berupa FRP 3-layer $(R+$ CSM $300+R+W R 800+R+C S M 300+$ $\mathrm{R})$;

b. Lapisan 2 (Bottom Shell) menggunakan Panel 4 FRP 6-layer tipe-3 ( $\mathrm{R}+$ $\mathrm{CSM} 300+\mathrm{CSM} 300+\mathrm{R}+\mathrm{WR} 800+\mathrm{R}+$ CSM $300+R+\operatorname{CSM} 300+$ CSM $300+$ $\mathrm{R})$.

Ketebalan pada masing-masing material pada kondisi optimal adalah sebagai berikut:

- $\operatorname{CSM~} 300=0.5 \mathrm{~mm}$;

- WR $800=0.54 \mathrm{~mm}$;

- Resin (asusmsi) $=0.15 \mathrm{~mm}$;

Dengan menggunakan asumsi ketebalan pada kondisi optimal, maka ketebalan pada model 1 lapisan side shell adalah 2.14 $\mathrm{mm}$, dan pada bottom shell adalah $4.13 \mathrm{~mm}$. Sedangkan ketebalan pada model 2 untuk lapisan side shell adalah $2.14 \mathrm{~mm}$, dan pada bottom shell adalah $3.79 \mathrm{~mm}$. 


\subsection{Hasil Simulasi Numerik Tegangan Lokal}

1. Model 1

a. Tegangan maksimum dan minimum model 1. Dengan menggunakan parameter yang telah diuraikan sebelumnya, maka didapat hasil analisa tegangan lokal pada model sebagai berikut:
Tabel 2 Hasil simulasi tegangan lokal pada model 1.

\begin{tabular}{|rr}
\hline \multicolumn{2}{c}{ Results } \\
\hline Minimum & $0.11887 \mathrm{MPa}$ \\
\hline Maximum & $108.1 \mathrm{MPa}$ \\
\hline
\end{tabular}

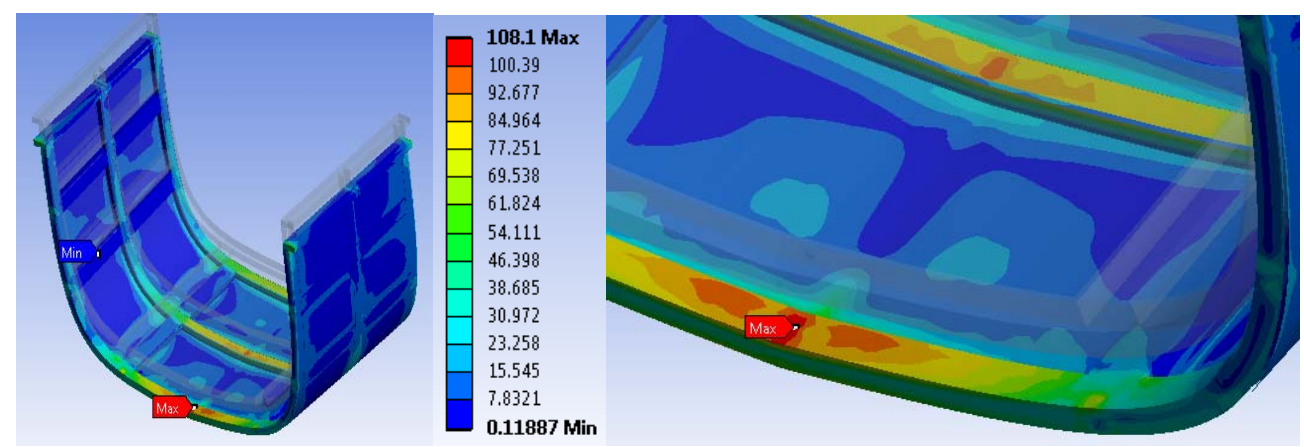

Gambar 9 Hasil simulasi tegangan model 1.

Dari tabel dan gambar diatas diketahui bahwa tegangan maksimum yang terjadi pada model adalah sebesar 108.1 $\mathrm{MPa}$, terjadi di bottom shell gading 17 . Sedangkan tegangan minimum yang terjadi pada model adalah $0.11887 \mathrm{MPa}$, terjadi di hampir seluruh side shell. b. Tegangan pada side shell untuk model 1 . Side shell memiliki ketebalan yang berbeda dengan bottom shell, sehingga perlu diketahui juga nilai maksimum tegangan yang terjadi. Berdasarkan hasil simulasi, nilai tegangan maksimum pada side shell adalah 54.111 MPa. Untuk lebih jelasnya dapat dilihat pada gambar 10 .
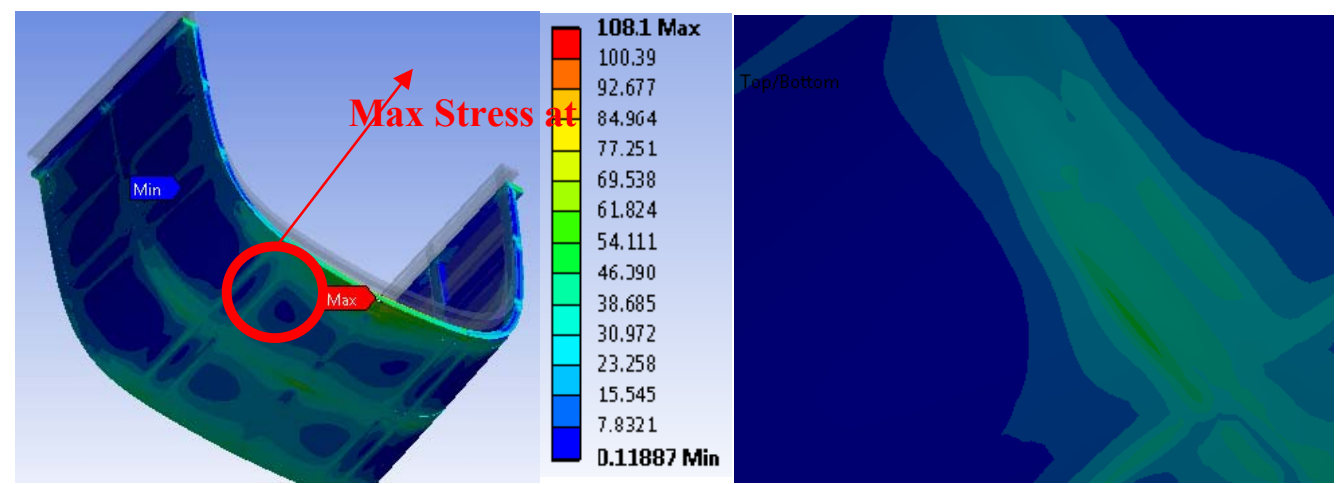

Gambar 10 Hasil simulasi tegangan side shell pada model 1

\section{Model 2}

a. Tegangan maksimum dan minimum model 2

Dengan menggunakan parame-ter yang telah diuraikan sebelumnya, maka didapat hasil analisa tegangan lokal pada model sebagai berikut:
Tabel 3. Hasil simulasi tegangan lokal pada model 2

\begin{tabular}{lr}
\hline \multicolumn{2}{c}{ Results } \\
\hline Minimum & $0.1097 \mathrm{MPa}$ \\
Maximum & $117.66 \mathrm{MPa}$ \\
\hline
\end{tabular}




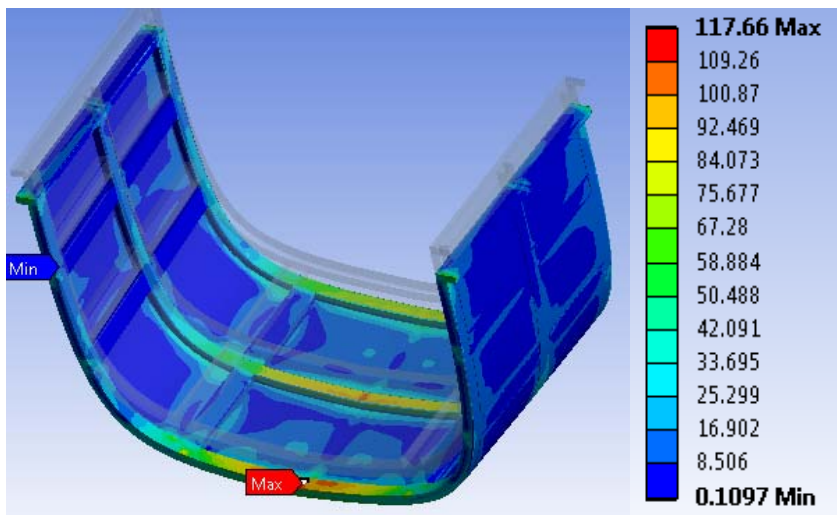

Gambar 11 Hasil simulasi tegangan model 2.

Dari tabel dan gambar diatas diketahui bahwa tegangan maksimum yang terjadi pada model adalah sebesar 117.66 MPa, terjadi di bottom shell gading 17 . Sedangkan tegangan minimum yang terjadi pada model adalah 0.1097 $\mathrm{MPa}$, terjadi di hampir seluruh side shell.

a. Tegangan pada side shell untuk model 2
Berdasarkan hasil simulasi, nilai tegangan maksimum pada side shell adalah $\mathbf{5 8 . 8 8 4}$ MPa. Untuk lebih jelasnya dapat dilihat pada gambar dibawah ini:

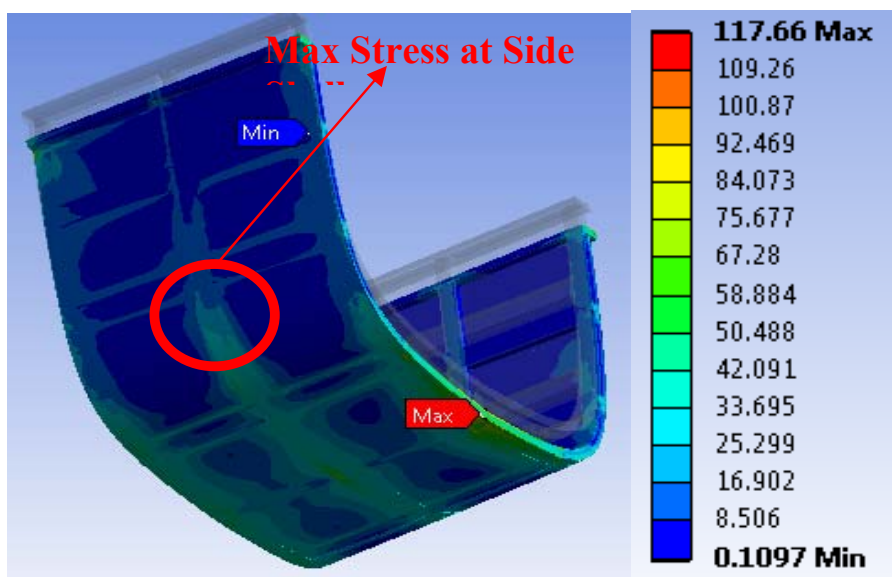

Gambar 12 Hasil simulasi tegangan side shell pada model 2.

\section{Hasil Pengujian Tarik Panel FRP di Laboratorium.}

Panel benda uji dibuat sesuai standard di Laboratorium dan dibuat masing masing komposisi laminasi sebanyak 5 buah, komposisi laminasi sebagai berikut;

a. Panel 1 berupa FRP 3-layer $(\mathrm{R}+\mathrm{CSM} 300+\mathrm{R}$ + WR800 + R + CSM300 + R)

b. Panel 2 berupa FRP 6-layer tipe-1 $(\mathrm{R}+$ $\mathrm{CSM} 300+\mathrm{R}+\mathrm{CSM} 300+\mathrm{R}+\mathrm{WR} 800+\mathrm{R}+$ WR800 + R + CSM300 + R + CSM300 + R); c. Panel 3 berupa FRP 6-layer tipe-2 ( $\mathrm{R}+$ CSM300 + CSM300 + R + WR800 + WR800 + $\mathrm{R}+\mathrm{CSM} 300+\mathrm{CSM} 300+\mathrm{R})$

d. Panel 4 berupa FRP 6-layer tipe-3 ( $R+$ CSM300 + CSM300 + R + WR800 + R + CSM300 + R + CSM300 + CSM300 + R).

Hasil Uji Tarik masing-masing panel yang dilakukan pada tanggal 4-12 september 2017 dapat dilihat dalam table dibawah ini. 
Tabel 4 Hasil uji tarik.

\begin{tabular}{|c|c|c|c|c|c|c|c|c|}
\hline $\begin{array}{c}\text { Specimen } \\
\text { no }\end{array}$ & $\begin{array}{c}\text { Dimensions } \\
(\mathrm{mm}) \\
\mathrm{b} \\
\end{array}$ & $\mathrm{H}$ & $\begin{array}{c}\text { Gage } \\
\text { Length } \\
(\mathrm{mm}) \\
\text { Lo } \\
\end{array}$ & $\begin{array}{c}\text { Area } \\
\left(\mathrm{mm}^{2}\right) \\
\text { A } \\
\end{array}$ & $\begin{array}{l}\text { Ultimate } \\
\text { Load } \\
(\mathrm{N})\end{array}$ & $\begin{array}{c}\text { Ultimate } \\
\text { Strength } \\
\text { (MPa) }\end{array}$ & $\begin{array}{l}\text { Rata-rata } \\
\text { Ultimate } \\
\text { Strength }\end{array}$ & $\begin{array}{c}\text { StdDev } \\
( \pm)\end{array}$ \\
\hline 1.A & 25.32 & 2.17 & 50.00 & 55.02 & 7500 & 136.31 & & \\
\hline 1.B & 25.22 & 2.03 & 50.00 & 51.27 & 8600 & 167.73 & & \\
\hline 1.C & 25.03 & 2.05 & 50.00 & 51.23 & 10400 & 202.99 & 175.73 & 22.79 \\
\hline 1.D & 25.07 & 1.85 & 50.00 & 46.38 & 8200 & 176.80 & & \\
\hline 1.E & 24.82 & 2.02 & 50.00 & 50.14 & 9550 & 190.45 & & \\
\hline 1.F & 25.07 & 1.96 & 50.00 & 49.14 & 8850 & 180.11 & & \\
\hline 2.A & 25.20 & 4.13 & 50.00 & 104.06 & 16350 & 157.10 & & \\
\hline 2.B & 25.20 & 4.22 & 50.00 & 106.34 & 15200 & 142.93 & & \\
\hline 2.C & 25.01 & 4.17 & 50.00 & 104.29 & 16500 & 158.21 & 157.41 & 7.92 \\
\hline 2.D & 24.92 & 4.24 & 50.00 & 105.66 & 16600 & 157.11 & & \\
\hline $2 . E$ & 25.16 & 4.34 & 50.00 & 109.19 & 18050 & 165.30 & & \\
\hline 2.F & 25.28 & 4.13 & 50.00 & 104.41 & 17100 & 163.78 & & \\
\hline 3.A & 25.19 & 3.96 & 50.00 & 99.75 & 19600 & 196.49 & & \\
\hline 3.B & 25.21 & 3.78 & 50.00 & 95.29 & 18650 & 195.71 & & \\
\hline 3.C & 25.02 & 3.75 & 50.00 & 93.83 & 19050 & 203.04 & 192.36 & 7.24 \\
\hline 3.D & 25.03 & 4.00 & 50.00 & 100.12 & 18900 & 188.77 & & \\
\hline $3 . E$ & 25.18 & 3.93 & 50.00 & 98.96 & 18250 & 184.42 & & \\
\hline 3.F & 25.17 & 3.69 & 50.00 & 92.88 & 17250 & 185.73 & & \\
\hline 4.A & 25.06 & 4.09 & 50.00 & 102.50 & 13750 & 134.15 & & \\
\hline $4 . B$ & 24.97 & 4.12 & 50.00 & 102.88 & 12900 & 125.39 & & \\
\hline 4.C & 25.28 & 4.06 & 50.00 & 102.64 & 13750 & 133.97 & 141.97 & 12.44 \\
\hline 4.D & 2517 & 3.85 & 50.00 & 96.75 & 14750 & 152.45 & & \\
\hline 4.E & 25.01 & 3.65 & 50.00 & 91.29 & 13650 & 149.53 & & \\
\hline 4.F & 25.29 & 3.92 & 50.00 & 99.14 & 15500 & 156.35 & & \\
\hline
\end{tabular}

\section{Perbandingan hasil analisa numerik dengan hasil pengujian}

Dari tabel diatas diketahui bahwa nilai tegangan maksimum baik side shell dan bottom shell lebih kecil dari tegangan maksimum yang dihasilkan dari benda uji baik dari uji tarik dan uji bending. Bila kondisi ini yang terjadi maka dapat diasumsikan bahwa konstruksi kapal 3GT tersebut aman. Namun, kondisi pada bottom shell lebih besar dari tegangan ijin rules BKI sebesar $98 \mathrm{Mpa}$.

Tabel 5 Perbandingan tegangan maksimum hasil simulasi dengan pengujian.

\begin{tabular}{cccccccccc}
\hline \multirow{2}{*}{ Item } & $\begin{array}{c}\text { Max. Stress at } \\
\text { Simulation - MPa }\end{array}$ & \multicolumn{2}{c}{$\begin{array}{c}\text { Ultimate } \\
\text { Strength } \\
\text { (average) - MPa }\end{array}$} & $\begin{array}{c}\text { Material } \\
\text { strength } \\
\text { BKI }\end{array}$ & $\begin{array}{c}\text { Safety factor } \\
\text { simulation }\end{array}$ & $\begin{array}{c}\text { Flexural Strength } \\
\text { (average) - MPa }\end{array}$ \\
\cline { 2 - 10 } & Model 1 & Model 2 & Model 1 & Model 2 & & Model 1 & Model 2 & Model 1 Model 2 \\
\hline $\begin{array}{c}\text { Bottom } \\
\text { Shell } \\
\text { Side } \\
\text { Shell }\end{array}$ & 108.1 & 117.66 & 157.41 & 141.97 & 98 & 1,45 & 1,2 & 209.162 & 183.79 \\
\hline
\end{tabular}

\section{KESIMPULAN}

Nilai tegangan maksimum dari hasil simulasi baik pada side shell ataupun bottom shell lebih kecil dari tegangan maksimum yang dihasilkan dari benda uji baik dari uji tarik dan uji bending. Bila kondisi ini yang terjadi maka dapat diasumsikan bahwa konstruksi kapal 3GT tersebut aman dengan safety factor $1.2 \infty 2.98$. Namun, bila dibandingkan dengan tegangan ijin dari rules $\mathrm{BKI}$ sebesar $98 \mathrm{Mpa}$, perlu menambah jumlah lapisan pada bottom shell atau menambah konstruksi memanjang pada kapal tepat di tengah bottom. Hal ini menjawab hipotesa bahwa meskipun jumlah lapisan dikurangi sesuai kearifan local untuk mendapatkan berat kapal yang lebih ringan tetapi masih memenuhi persyaratan dan kebutuhan kekuatan material kapal untuk bentuk dan ukuran kapal 3GT. 


\section{UCAPAN TERIMAKASIH}

Ucapan terimakasi yang sebesar-besarnya kepada Bapak Ir. Usman Effendi, MM selaku pelaksana tugas Kelapa BBPI Semarang dan seluruh jajarannya yang telah memberi kesempatan, fasilitas dan dukungannya kepada kami untuk dapat melakukan kajian hingga tersusunnya makalah ini.

\section{DAFTAR PUSTAKA}

ANSYS Inc. 2013. User Manual.

Buana Ma'ruf. (2011) Studi Standardisasi Konstruksi Laminasi Lambung Kapal Fiberglass. UPT Balai Pengkajian dan Penelitian Hidrodinamika. BPPT. Jurnal Standardisasi Vol.13 No.1:16-25.

Chen, N.Z., Soares, C.G. (2007) Longitudinal Strength Analysis of Ship Hulls of Composite Materials under Sagging moments. Unit of Marine Technology and engineering, Technical University of Lisbon. Journal of Composites Structures 77.: 36 - 44.

Budianto. (2016) Analisis Fatigue pada struktur Kapal Penangkap Ikan 30 GT. Jurnal Kelautan Universitas Trunojoyo Vol.9 No.2

Mansyur Hasbullah, A Haris Muhammad, M Rizal Firmansyah. (2010) Design Kapal FRP Berbasis Lingkungan dan Penggunaan Material. Prosiding Penelitian Teknologi Kelautan. Jurusan Perkapalan Fakultas Teknik Universitas Hasanuddin. Makassar.

Maxsurf User Guide. 2014.

Hetharia Wolter R., Metekohy Obed. (2017) Design and Application of Unsinkable Tuna Longboat for Local Fishermen. Occasional Papers No.58. Faculty of Engineering, Pattimura University..

Huynh Van-Vu, (2015) Prediction the Ultimate Longitudinal Strength of Intact Ship by Finite Element Method, International Journal of Mechanical Engineering and Applications. Special Issue: Transpor-tation Engineering Technology. Vol. 3, No. 1-3, , pp. 18-23.

IIma, I.R., Handayanu, Murteji, M. (2011) Analisa Kekuatan Struktur antara Deck dan Lambung Bagian Dalam Kapal Katamaran. Teknik
Kelautan Institut Teknologi Sepuluh Nopember Surabaya. Jurnal Tugas Akhir..

Konstantinos Galanis. (2002) Hull Construc-tion with Composite Materials for Ships over 100 $\mathrm{m}$ in length. Hellenic Naval Academy. Massachusetts Institute of Technology.

Parlindungan Manik, Eko Sasmito Hadi. (2008). Analisa Teknis Dan Ekonomis Penggunaan Coremat Untuk Konstruksi FRP (Fiberglass Reinforced Plastic) Sandwich Pada Badan Kapal. Jurnal IImu Pengetahuan \& Teknologi Kelautan, Kapal, Vol. 5, No. 2. Program Studi Teknik Perkapalan, Fakultas Teknik, Universitas Diponegoro. Semarang..

Rutherford, S.E, Caldwell, J.B. (1990) Ultimate longitudinal Strength of Ships: A Case Study. SNAME Transaction Vol. 98,: 441 471

Shahrin Febrian. (2013) Pengujian Awal Konstruksi Fiberglass Pada Lambung Kapal Boat Sesuai Standar. Prodising Seminar Hasil Penelitian Semester Genap 2012/2013 "Meningkatkan Mutu dan Profesionalisme Dosen melalui Penelitian", Tahun I, No.2. Lembaga Penelitian, Pemberdayaan Masyarakat dan Kemitraan, Universitas Darma Persada.

Sitepu, G., Rauf, A.M. (2011) Perangkat Lunak Perhitungan Kekuatan Longitudinal Kapal. Jurusan perkapalan Fakultas Teknik Universitas Hasanuddin. Hasil Penelitian Fakultas Teknik. Prosiding.

Suman Kar, D.G. Sarangdhar, G.S. Chopra. (2008) Analyses of Ship Structures Using ANSYS. Sea Tech Solutions International (S) Pte Ltd. Conference paper Tahun: 1 - 13

Tjuk Oerbandono, Agustian Adi Gunawan, Erwin Sulistyo. (2015) Karakteristik Kekuatan Bending dan Impact akibat Variasi Unidirectional Pre-Loading pada Serat Penguat Komposit Polyester. Proceeding Seminar Nasional Tahunan Teknik Mesin XIV (SNTTM XIV). Banjarmasin.

Zweben, Carl. (2015) Mechanical Engineer's handbook Fourth edition, chapter 10: Composites Material. John Wiley \& Sons Inc. 
Jurnal Standardisasi Volume 19 Nomor 3, November 2017: Hal 255 - 264

 